To succeed on a global scale, businesses

should focus on a trio of key elements.

BY SIEW KIEN SIA, CHRISTINA SOH, AND PETER WEILL

\title{
Global IT \\ Management Structuring for Scale, Responsiveness, and Innovation
}

\author{
GLOBALIZATION IS A significant factor in today's business \\ strategies, ${ }^{8}$ as companies in mature markets \\ seek growth by expanding their operations in the \\ emerging markets of Asia, Latin America, Eastern \\ Europe, and the Middle East. These multinational \\ companies (MNCs) have to extend their existing \\ portfolio of IT applications, infrastructure, and \\ services to support their global business strategies.
}

However, managing globally distributed IT resources is challenging. Visibility of such resources is often poor, as the local IT unit may not report back to central IT, and in many firms there is no enterprisewide IT budget management. For most firms there is also an inherent global-local tension to simultaneously achieve three strategic objectives: scale, responsiveness, and innovation. To balance the trade-offs, practice and research in the structural design of IT has moved away from the IT centralization-versus-decentralization debate to more nuanced forms of IT organizational design. These include the federal structure, ${ }^{14}$ hybrid governance, ${ }^{6}$ "centrally decen- tralized" governance, ${ }^{17}$ and matrixed governance. ${ }^{18}$

These "hybrid" structures recognize that the various types of IT activities have different operating characteristics and economics and thus should be managed differently. Some researchers, for example, have found the management of IT infrastructure is usually centralized, while the management of IT use is often decentralized. The development of IT applications resides in the local units for some organizations, or at central IT for others, while a third group has applications development capabilities at both central and local units. Agarwal and Sambamuthy ${ }^{1}$ noted three 
variants - the partner, platform, and scalable model-where the decision rights for each of eight IT value processes (for example, infrastructure management, solutions delivery, and strategic planning) could be centralized, decentralized, or shared. Allocating decision rights differently for different IT activities was also at the heart of the matrix governance proposed by Weill and Ross ${ }^{19}$ - who identified different configurations for making five key IT decisions-IT principles, IT architecture, IT infrastructure, business application needs, and IT investment and prioritization.

The features of hybrid structures remain under-studied, particularly as increasing globalization has resulted in continuing evolution of the structure of the IT function. Ineffective global IT structures result in the duplication of resources, proliferation of IT systems, increased complexity and risk, and the compromise of key business requirements such as agility. Here, we ask how are hybrid IT structures implemented in the global context to balance the global-local tensions while achieving scale, responsiveness, and innovation?

\section{Structuring the Global IT Organizations}

We examine this question through in-depth studies of four industry leading MNCs that have established a strong global presence, particularly in emerging markets such as Asia. The four companies represent a diverse set of industries. Microsoft develops, manufactures, licenses, and markets software in 90 countries. Intel is the world's largest producer of semiconductor chips and operates in 60 countries. Procter and Gamble is a leading manufacturer and marketer of consumer products in three sectors-beauty care, household care, and health and well being-across more than 180 countries. Underwood Financials (pseudonym), is among the top 10 investment banks globally, operating in 60 countries, and continues

Table 1. Examples of P\&G Global Business Services.

\begin{tabular}{|c|c|}
\hline Employee Services & Pay, benefits, policies, career development, work plans \\
\hline People Management & $\begin{array}{l}\text { Compensation planning, relocation, employee } \\
\text { management tools }\end{array}$ \\
\hline Facilities & $\begin{array}{l}\text { Office moves, conveniences: banking, dining, fitness centers, } \\
\text { mail and documents }\end{array}$ \\
\hline Computers and Communications & PCs, email, mobile phones, Intranet, service support \\
\hline Meetings & $\begin{array}{l}\text { Rooms, technology and scheduling, audio and video } \\
\text { conferencing, events }\end{array}$ \\
\hline Travel & Booking, expense accounting, credit cards, group meetings \\
\hline \multicolumn{2}{|l|}{ Business Services and Solutions } \\
\hline $\begin{array}{l}\text { Strategic Sourcing and } \\
\text { Procurement }\end{array}$ & $\begin{array}{l}\text { Strategic sourcing, supplier relationship management, } \\
\text { procurement service }\end{array}$ \\
\hline Financial Services and Solutions & $\begin{array}{l}\text { General ledger, affiliate accounting, product/fixed asset } \\
\text { accounting, SRAP/MSA accounting, purchases-to-payment } \\
\text { (include accounts payable), banking, financial reporting }\end{array}$ \\
\hline Product Innovation & $\begin{array}{l}\text { Bioinformatics systems, product imaging and } \\
\text { modeling systems }\end{array}$ \\
\hline Supply Network Solutions & $\begin{array}{l}\text { Demand planning systems, total order management, } \\
\text { physical distance systems }\end{array}$ \\
\hline Consumer Solutions & $\begin{array}{l}\text { Prime prospect research, CRM systems, advertising and } \\
\text { media measurement }\end{array}$ \\
\hline Customer Solutions & $\begin{array}{l}\text { Shopper intelligence, in-store action planning, trade fund } \\
\text { management systems }\end{array}$ \\
\hline Initiative Management & $\begin{array}{l}\text { Technical package and materials design, package artwork } \\
\text { process, portfolio tracking, and reporting }\end{array}$ \\
\hline Business Performance Solutions & $\begin{array}{l}\text { Decision cockpits, market mix modeling, competitive } \\
\text { intelligence, ad hoc business analyses }\end{array}$ \\
\hline
\end{tabular}

to perform relatively well even in the current economic downturn.

We interviewed between two and six executives (a few with multiple interviews) in each firm including the CIO, examined internal documents such as organization charts, and publicly available information such as annual reports, analyst reports, and news reports. Our interview questions were concerned with how these companies had set up and managed their global IT structures with a particular focus on the fast-growing Asian region.

Our findings showed that, despite the variation in industry, all the MNCs studied used three common structural elements to link the enterprisewide IT leadership (who design and oversee enterprisewide IT governance, the IT budget, and portfolio management, enterprise architecture, and enterprise risk management), and the more locally focused concerns of the business units. Although companies sometimes labeled these elements differently, such as, shared services, centers of excellence (CoEs), and value managers (VMs), the goals of each element were the same across the firms. The objective of shared services was to achieve scale economies; the objective of CoEs was to drive innovation; and the objective of value managers was to enable responsiveness. The three structural elements are described here in detail.

IT Shared Services are structural units that consolidate common IT functions (for example, helpdesk, operations, development) to achieve scale by providing standardized services. Such sharing eliminates unnecessary duplication of IT resources and improves utilization of IT assets. Global MNCs often have three shared service units located in the Americas, Europe, and Asia focused on delivery within their respective regions and serving as backups for the other regions. Microsoft, for example, created regional shared services at Richmond (corporate headquarters serving North America), Dublin (serving Europe, Middle East, and Latin America), and Singapore (serving Asia) to manage IT services across the globe.

Shared service units can offer a wide range of IT services, allowing the local business units to choose from 
a catalog of IT services. The globallocal tension here is to encourage local units to use more of the shared services while still meeting the diverse needs of the local units. For example, as a $\$ 90$ billion global enterprise operating in more than 180 countries and marketing over 250 brands to nearly five billion consumers, P\&G created the Global Business Services (GBS) unit in 1999. GBS provides a set of 70 IT services on a global scale with published IT unit costs and service-level agreements. To provide around-theclock business support worldwide, three shared-services centers have been built: in San Jose, Costa Rica; in Newcastle, U.K.; and in Manila, Philippines. GBS strategy is to provide bestin-class business support services at the lowest possible costs.

P\&G draws on its strong marketing culture to package and offer a catalog of services to its business units across the globe. The catalog embodies two principles of effective marketingsimplicity and choice (with transparent pricing). P\&G filters the "bestin-class" service offerings down to a single-page catalog in two "shopping aisles"-Employee Services and Business Services (see Table 1). Brands who consume these services still have control and choice even though some of the solutions are mandated. Within the mandated solutions, there are several tiers of service with different prices. Brand units can influence their costs by choosing a tier of service and influencing the number of units of service consumed. Pricing is also dependent on the region. To encourage business units to adopt the shared solutions, GBS guarantees a 10\%-30\% cost reduction initially.

An annual "glide-path" of unit price reduction is also built in. Brand units are thus incentivized to phase out their local services increasing the shared service stack to achieve more global scale and allowing the local units to focus more on meeting the needs of the external customer. Another benefit of shared services is to make the cost of each IT service transparent so it can be managed. Previously these costs were often hidden or not managed. To achieve such flexible service delivery requires sophisticated IT financial management. IT service design, internal marketing, pricing, and service optimization and innovation are performed by $P \& G$ personnel while the delivery is outsourced. GBS's capability extends beyond IT including financial, sourcing, and HR services. P\&G have identified over $\$ 600$ million in savings from shared services and credits GBS in helping to absorb its large acquisition of Gillette in only 15 months. $^{4}$

For the MNCs we studied, IT shared services achieved scale by brokering and incentivizing the use of standardized IT services across the firms, thus removing cost, duplication, and complexity. Some MNCs then outsourced the bulk of those shared services to external service providers who have even greater economies of scale.

IT Centers of Excellence (CoEs) are also known as competency centers or centers of expertise. CoEs are units that contain strategic IT capabilities identified by the firm as important sources of value creation and service innovation. CoEs are specialized units where the MNCs pool expertise physically or virtually across the globe. These units often do not have operational responsibilities but they serve as strategic resources that focus on designing and developing new solutions, such as, to innovate, and to develop depth in critical expertise. CoEs we encountered included those focused on application development, key business processes (for example, trade processing) and specific technologies or IT platforms (for example, EDI).

Underwood Financials has groups of IT experts who are co-located with the respective global product heads (foreign exchange, bonds, money market, equities, among others) in the HQ where new innovations in financial products typically occur. These IT specialists have in-depth IT and business domain expertise, and they work closely with the business to design and develop new IT solutions. The bank's ability for fast-to-market product launch globally is often dependent on their ability to respond with the necessary IT solutions. The day-today operations of the specific product platforms developed are handled by the shared services. These IT experts serve only as a third-level support for complex problems that cannot be re- solved by first- and second-level technical support.

Microsoft, similarly, has created the Corporate Solution Deliveries (SD) group comprised of specialized IT application developers led by about 40 solution directors who are located with the businesses and work closely with senior VPs in each major line of business to translate their intimate business understanding into the designing and developing global solutions. In the case of Intel, such pools of IT experts are known as Capability Groups and they focus on enhancing four major IT application development capabilities, namely, the supply-net capability, customer capability, enterprise capability, and platform capability. The customer capability group even reports outside IT to Sales and Marketing for tighter business-IT alignment in developing innovative IT solutions.

As CoEs are designed to provide the firm expertise and innovation in critical areas, they are typically centrally coordinated with the head office identifying the areas of excellence and where they will be located. MNCs are beginning to locate some of their IT CoEs in Asia to take advantage of local talent and cost advantages. P\&G located its CoE for mobile marketing in the Philippines to tap into the high usage of mobile phones in Asia. As part of the company's strategic innovation initiative the innovations from this CoE will be diffused to the global market.

Value Managers (VMs) are groups of IT managers that seek to maximize the value of IT for specific business units. VMs, sometimes called customer relationship managers, focus on the IT needs for business units, business functions, and large or fast growing geographical markets. Within the constraints laid out by central IT, the VMs must ensure key business requirements unique to these customers are not overlooked. They build deep relationships with these business customers and support their needs for responsive IT globally. VMs are organized so that the voices of its key customers can be heard, consolidated, and appropriately channeled for prioritization. Equally important, effective VMs also have responsibility to help implement enterprisewide IT initiatives within these customer units. Examples of 


\begin{tabular}{|c|c|c|c|}
\hline $\begin{array}{l}\text { Structural } \\
\text { Elements }\end{array}$ & Objective & Organization & Approach \\
\hline $\begin{array}{l}\text { IT Shared } \\
\text { Services }\end{array}$ & $\begin{array}{l}\text { To achieve global/regional } \\
\text { scale for cost efficiency } \\
\text { while allowing some local } \\
\text { choices via } \\
\text { global scale/scope } \\
\text { global sourcing } \\
\text { of IT resources } \\
\text { global common } \\
\text { platform } \\
\text { Heavily resource-intensive } \\
\text { KPIs: service level } \\
\text { agreement, unit cost, } \\
\text { simplicity }\end{array}$ & $\begin{array}{l}\text { By major IT functions, } \\
\text { IT or business process } \\
\text { services: } \\
\text { catalog of services } \\
\text { offered, for example, } \\
\text { application and } \\
\text { infrastructural services } \\
\text { typically located in } \\
\text { lower cost regions } \\
\text { some services } \\
\text { outsourced to external } \\
\text { vendors. }\end{array}$ & $\begin{array}{l}\text { Drive scale via: } \\
\text { - active service } \\
\text { management and } \\
\text { transparency } \\
\text { - standardization } \\
\text { consolidation } \\
\text { - process improvement } \\
\text { - service quality } \\
\text { - sourcing }\end{array}$ \\
\hline $\begin{array}{l}\text { IT Centers } \\
\text { of Excellence }\end{array}$ & $\begin{array}{l}\text { To innovate and develop } \\
\text { best practices via } \\
\text { global coordination } \\
\text { of capabilities } \\
\text { global pooling } \\
\text { of IT expertise } \\
\text { Heavily knowledge- } \\
\text { intensive } \\
\text { KPIs: \# of new global } \\
\text { solutions developed, time to } \\
\text { market for new application, } \\
\text { reuse of best practice } \\
\text { across firm, business } \\
\text { process performance, and } \\
\text { so on. }\end{array}$ & $\begin{array}{l}\text { By innovative technologies } \\
\text { or strategic capabilities: } \\
\text { centrally coordinated } \\
\text { may be located } \\
\text { outside HQ } \\
\text { can be virtual by } \\
\text { pooling distributed } \\
\text { experts }\end{array}$ & $\begin{array}{l}\text { Drive innovation via: } \\
\text { pooling deep } \\
\text { internal knowledge } \\
\text { and expertise } \\
\text { investment into } \\
\text { experimentation } \\
\text { and innovation } \\
\text { - applying and sharing } \\
\text { best practices } \\
\text { enterprisewide }\end{array}$ \\
\hline $\begin{array}{l}\text { IT Value } \\
\text { Managers }\end{array}$ & $\begin{array}{l}\text { To maximize the value } \\
\text { of IT for specific groups } \\
\text { in the firm via } \\
\text { being responsive to } \\
\text { local needs through } \\
\text { a single face of IT } \\
\text { advocating for } \\
\text { customer units } \\
\text { to central IT } \\
\text { helping implement } \\
\text { enterprisewide } \\
\text { initiatives locally } \\
\text { Heavily relationship- } \\
\text { intensive } \\
\text { KPIs: customer } \\
\text { satisfaction, business-IT } \\
\text { alignment, partnership } \\
\text { maturity, among others. }\end{array}$ & $\begin{array}{l}\text { By major business } \\
\text { dimensions: } \\
\text { strategic lines } \\
\text { of business } \\
\text { important business } \\
\text { functions } \\
\text { large or fast growing } \\
\text { geographical markets } \\
\text { major external } \\
\text { customers }\end{array}$ & $\begin{array}{l}\text { Push for responsiveness } \\
\text { via: } \\
\text { proximity to customer } \\
\text { units to capture voice } \\
\text { of the customer } \\
\text { simultaneous proximity } \\
\text { to central IT } \\
\text { constructive negotiation } \\
\text { and facilitation of } \\
\text { conflict resolution }\end{array}$ \\
\hline
\end{tabular}

centrally initiated enterprisewide programs are global ERP implementations, collaboration tools, and costcutting efforts. One CIO put it well: "Without the second objective of implementing enterprisewide initiatives those folks (VMs) go feral and have loyalty only to the local units."

Microsoft has an extended field IT structure that covers its geographical market across 106 countries. Field IT is overseen by an International IT VP reporting to the Global CIO. Below the International IT VP are the IT managers for three regions: North America, Europe/Middle East/Latin America, and Asia. The Asia region, for example, further cascades down to 13 regional clusters. These IT managers play a brokering role, such as in representing Central IT to influence and negotiate with the regional business own- ers, as well as the customer advocates in championing the interests of these business units and ensuring they derive adequate value from IT.

In one MNC, for example, when a new business in a major Indian city required an application for its fastgrowing business, the local general manager wanted it delivered in six weeks, and was willing to pay for the required resources. Conformance with the global organization's IT approval, development, and quality processes, however, would require six months. The IT manager (VM) assessed that delay would impact the business growth, and negotiated a solution to put a program manager to work with the local GM's resources in meeting the local business' timeline. The VM ensured the new system met global guidelines on security and architecture. In another example, the global human resource application was unable to handle the high volume of recruitment in an Asian office. As the time required to change the global application would take too long, the IT manager (VM) negotiated for a short-term module to be created, while providing input to the global applications team. The short-term module would be used until the rollout of the next version of the global HR solution which included the new requirement to process the higher recruitment volume.

The "voice of the field" provided through the VMs in emerging markets can also be a source of global innovation. Through such feedback, P\&G recognized the need for new IT applications to cater to the needs of Asian businesses. In one example, P\&G noted a difference in the sales distribution model as Asian consumers tend to shop more frequently and in smaller quantities, and hence, began developing IT systems to support the fast growing "high frequency stores" segment. These systems are expected to be useful in other emerging regions as well. Another example is P\&G's SKII beauty product, which originated in Japan and has grown to become one of the premium brands in the global cosmetic market. The product distribution for SKII operated on a different business model from P\&G's mass market positioning, as it was sold in department stores with dedicated 
counter sales consultants. To support the high-touch sales model, systems were built to automate counter operations, to track transactions for each customer, and to provide analysis of sales/marketing plans by customer segment. The systems significantly increased the efficiency for the thousands of sales consultants in Japan. The SKII line, together with the enabling systems, has been successfully deployed to the rest of the world.

Table 2 summarizes the general characteristics of these three structural IT elements, across the companies that we studied.

\section{Configuring the Global- Local Balance in the Structural Elements}

Although the four MNCs we studied are from different industries, they all had implemented similar structural elements of shared services, CoEs, and VMs. This observation suggests some convergence regarding the global structuring of IT resources, as they all seek to simultaneously achieve global scale, while providing local responsiveness and innovation. The accompanying figure summarizes the model for structuring global IT that emerges from our study.

However, multinationals still need to make trade-offs among these strategic objectives. Managers seek these trade-offs by varying configuration of each structural element and distributing resources among them. One of the most common trade-offs we observed was between achieving scale and responsiveness. Companies that sought greater scale tended to have a single global shared service unit. Underwood Financials, for example, has a single global shared service unit in Singapore that serves all business units worldwide over three work shifts. While first-line support was available $24 \times 7$, more sophisticated level 3 support was still centralized at headquarters. Responsiveness to complex problems that occurred in other time zones was therefore a challenge. At the time of this study, the head of shared services was lobbying for level 3 support in the Asian time zone as well. Other MNCs traded off global scale for greater regional responsiveness. Microsoft, for example, operates three regional shared services units, covering North America, Europe-Middle East-Africa and Latin America, and Asia respectively.

The configuration of CoEs also reflected trade-offs between local and more global innovation. While most CoEs tend to be global because such specialized expertise is usually costly and in tight supply, companies vary in whether they choose to locate the CoEs at HQ, or abroad, or to create virtual CoEs that pool expertise virtually across several geographies. Underwood Financials' application development $\mathrm{CoE}$ for its financial products resides with its business headquarters, which allows it to more tightly link its innovation activities to corporate strategy. P\&G, on the other hand, has begun to experiment with locating some of its CoEs abroad, for example, its global mobile marketing CoE is in the Philippines. This is a response to the pervasiveness of mobile communications in Asia. Less commonly, MNCs attempt to achieve even greater responsiveness of local conditions by establishing CoEs at the regional level if there is significant disparity in institutional context, for example, having a separate regional SAP Competency Center in China to address the different language and its unique requirements. The trade-off is in the replication of resources, and greater coordination challenges of aligning local innovation with corporate direction.

MNCs, such as Underwood Financials that have prioritized scale through having a single global shared service center, and also global CoEs located at HQ, clearly are at risk of not responding adequately to legitimate regional or local concerns. In the case of Underwood Financials, they attempted to address this by creating a hierarchy of VMs. Within each region, there are VM roles at the intersection of product lines and region. For example, there would be VMs for bondsAsia Pacific, bonds-Europe, and so on. These VMs had a matrix reporting structure to both the line of business, and to the regional CIOs. There were various forums that brought together VMs, with business and global IT services and CoEs, as a means to promote coordination and communication within this complex organization structure. Hence, while Underwood Financials reaped scale efficiencies from having global shared services and CoEs, it invested in its elaborate VM structure to be more responsive to local needs.

\section{A model for structuring global IT.}

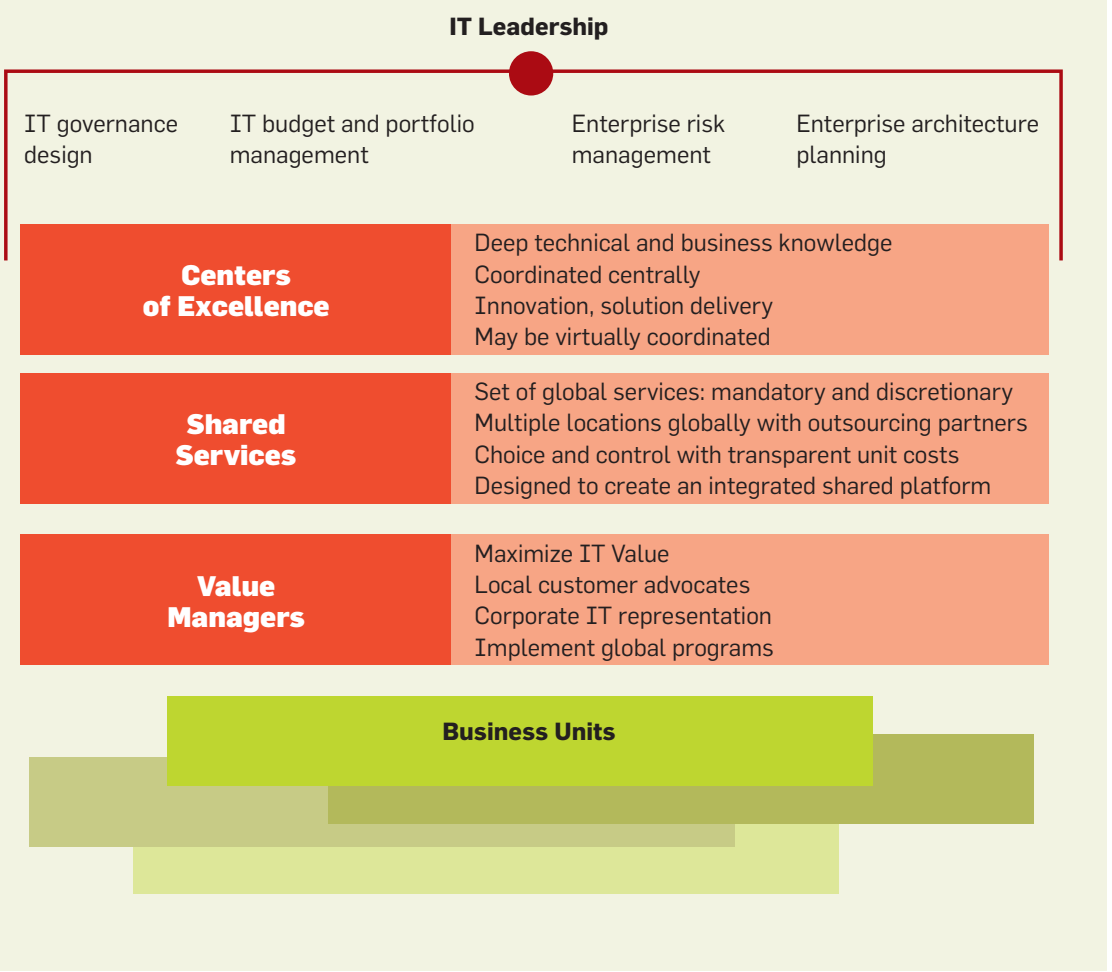


We found VMs play a critical role in ensuring the inherent tensions between scale, responsiveness, and innovation are played out constructively in each business and region. The selection and training of VMs, as well as ongoing support, is critical. For example, Intel actively grooms IT managers who can appreciate both the global and local perspectives. Intel selects high-potential local individuals, exposes them to various "extracurricular activities" such as IT cost reduction initiatives, and sends them on yearlong postings in other roles. Intel also rotates some of its best people in other parts of the world through management stints in Asia to encourage a balanced global-local view so that more informed trade-offs can be made.

The VMs' role in constantly mediating between local demands and corporate policy can be wearing. In some MNCs, VMs who thrived did so by developing and drawing upon an informal network that comprised contacts in the business, corporate IT, and other

VMs. The ability to quickly access the right people in the network appeared to enhance their ability to find solutions to global-local problems. Underwood Financials' various forums helped to develop such networks, as did Intel's approach to rotating its managers.

MNCs' trade-offs between scale, innovation, and responsiveness need to be made taking into account a complex mix of factors including: industry, size, desired levels of synergies, access to skilled people, and the roles of scale, innovation and responsiveness in the business model. Table 3 lists some of the questions we suggest CIOs consider in deciding the extent of scale, innovation, and responsiveness desired.

Globalization is an opportunity for CIOs to demonstrate business leadership. Shared services, CoEs, and VMs are structural elements that CIOs are increasingly using to re-bundle traditional IT resources to simultaneously deliver on scale, responsiveness, and innovation. We have observed that successful development of such IT

Table 3. Discussion questions for the design of structural elements in global IT.

Structural Elements

IT Shared Services

\section{Discussion Questions}

What is the desired level of scale to be derived from IT shared services?

Is your product or service global or commoditized? Is there significant value added from local variations?

What are the factors that contribute to scale in your industry (for example, common customers, processes, resource, or information)?

What are the common IT applications and infrastructure services that can be bundled to be offered through shared services?

How are cost shared across the firm (for example, chargeback by service, overhead absorption depending on size, and so on)?

IT Centers of Excellence

Do you need to coordinate IT enabled innovation?
Are your company's market offerings and competitive advantage driven by innovation in process, product, and/or technology?

What are the strategic IT capabilities that can contribute to the future competitive advantage?

What IT capabilities can benefit from regional or global pooling of expertise for continuous innovation?

IT Value Managers What is the desired level of IT responsiveness to local needs?

Who are the key user groups (for example, business units, business functions, fast-growing geographical markets) that IT must serve?

How different are the IT needs of these user groups?

What is the right balance of implementing enterprisewide IT initiatives and meeting local IT needs? managerial capabilities can deliver significant competitive advantage.

\section{References}

1. Agarwal, R. and Sambamurthy, V. Principles and models for organizing the IT functions. MISQ Executive 1, 1 (2002), 1-16.

2. Allen, B.R. and Boynton, A.C. Information architecture: In search of efficient flexibility. MIS Quarterly 15, 4 (1991), 435-445.

3. Bartlett, A.B. and Ghoshal, S. Managing Across Borders: The Transnational Solution. Harvard Business School Press, 2002

4. Bloch, M. and Lempres, E. From internal service provider to strategic partner: An interview with the head of Global Business Services at P\&G. McKinsey Quarterly (July 2008)

5. Brown, A.E. Framing the frameworks: A review of IT governance research. Communications of the AIS 15 (2005), 696-712

6. Brown, C.V. Examining the emergence of hybrid governance solutions: Evidence from a single case study. Information Systems Research 8, 1 (1997), 69-94.

7. Brown, C.V. and Magill, S.L. Reconceptualizing the context-design issue for Information Systems function. Organization Science 9, 2 (1998), 176-194.

8. Brown, J.S., and Hagel III, J. Innovation blowback: Disruptive management practices from Asia. McKinsey Quarterly 1 (2005)

9. Ein-Dor, P. and Segev, E. Organizational context and MIS structure: Some empirical evidence. MIS Quarterly 6, 3 (1982), 55-68.

10. Fonstad, N.O., and Robertson, D. Transforming a company, project by project: The IT engagement model. MISQ Executive 5, 1 (2006), 1-13.

11. Gallagher, K.P., and Worrell, J.L. Organizing IT to promote agility. Information Technology and Management 9, 1 (2008), 71-88.

12. Ghemawat P. Distance still matters: The hard reality of global expansion. Harvard Business Review, Sept. 2001.

13. Santos, J., Doz, Y., and Williamson, P. Is your innovation process global? Sloan Management Review, Summer 2004

14. Sambamurthy, V. and Zmud, R.W. Arrangements for information technology governance: A theory of multiple contingencies. MIS Quarterly 23, 2 (1999), 261-290.

15. Schwarz, A., and Villinger, R. Integrating Southeast Asia's economies. McKinsey Quarterly 1, 2004.

16. Tavakolian, H. Linking the Information Technology structure with organizational competitive strategy: A survey. MIS Quarterly 13, 3 (1989), 309-317.

17. Von Simson, E.M. The recentralization of IT. Computerworld 29, 51 (1995), 1-5.

18. Weill, P. Don't just lead, govern: How top-performing firms govern IT. MISQ Executive 3, 1 (2004), 1-17.

19. Weill, P. and Ross, J.W. A matrixed approach to designing IT governance. Sloan Management Review 48, 2 (2005), 26-34.

20. Weill, P. and Ross, J. IT Governance. Harvard Business School Press. Boston, MA, 2004

21. Yin, R.K. Case Study Research: Design and Methods. Sage Publications, Beverly Hills, CA, 1984.

22. Zmud, R.W. Design alternatives for organizing Information Systems activities. MIS Quarterly 8,2 (1984), 79-93.

23. Zmud, R.W., Boynton, A.C., and Jacobs, G.C. The information economy: A new perspective for effective information systems management. Data Base 18, 1 (1986), 17-23.

Siew Kien Sia (asksia@ntu-edu sg) is an associate professor and director of the Information Management Research Center at Nanyang Technological University, Singapore.

Christina Soh (acsoh@ntu-edu.sg) is an associate dean and professor at Nanyang Technological University, Singapore.

Peter Weill (pweill@mit.edu) is chair of the Center for Information Systems Research and Senior Research Scientist at MIT Sloan School of Management, Cambridge, MA. 